\title{
Effect of corticosteroid and corticotrophin therapy on adrenocortical function in bronchial asthma
}

\author{
J.R. KILBOR N A N D A. O.ROBSON \\ From the Departments of Medicine and Clinical Biochemistry, University of Newcastle upon Tyne and \\ Royal Victoria Infirmary, Newcastle upon Tyne
}

In a previous paper (Robson and Kilborn, 1965) we described some observations on adrenocortical function in continuous asthma. The methods employed were the cortisol production rate using an isotope dilution method (De Witt, Robson, and Stewart, 1962) and the specific measurement of plasma cortisol during adrenocorticotrophic hormone (A.C.T.H.) stimulation by a continuous intravenous infusion (Cameron and Kilborn, 1964). The patients were investigated when their asthma was quiescent, and no patient had previously received corticosteroid therapy.

The results obtained showed that the cortisol production rate (21 patients) was within normal limits, but in 23 of 34 patients (68\%) the adrenal cortex showed a diminished response to stimulation by A.C.T.H. The reason for the diminished reserve remained uncertain. It seemed conceivable that it could be due to a primary defect of the adrenal cortex or, on the other hand, secondary to a defect in A.C.T.H. production by the anterior pituitary.

Further study seemed to be necessary, not only in regard to the above problem, but for the practical management of the disease. It appeared to be important to investigate the effect of treatment with corticosteroid drugs and corticotrophin on the adrenal function in these patients.

With these points in mind, it was decided to reassess adrenal function in two groups of the original patients after treatment, one group having received prednisone and the other A.C.T.H.

\section{SUBJECTS AND METHODS}

The subjects were patients with continuous asthma $\vec{\oplus}$ in whom the adrenal function had been assessed $O$ (Robson and Kilborn, 1965) and in whom corticosteroid or corticotrophin therapy was indicated clinically. The prednisone group consisted of 14 of the first 21 patients to be investigated, and the A.C.T.H. group consisted of the subsequent 13 patients. One patient was excluded from the A.C.T.H. group when she became pregnant. The two groups are comparable for age, sex, duration of asthma, and in their initial response to A.C.T.H. stimulation (Table I).

The prednisone group received prednisone, $5 \mathrm{mg}$. t.d.s., for a minimum period of three months, and the A.C.T.H. group received A.C.T.H., 20 units i.m. daily, for a minimum period of two months. The periods of treatment were selected arbitrarily, but it was thought that they were of a sufficient duration to obtain the full effect on the adrenal cortex of the particular treatment.

The methods used have been described in detail previously (Robson and Kilborn, 1965). They consisted of an estimation of the cortisol production rate by an isotope dilution method, which measures the total mass of metabolites derived from cortisol alone (Cope and Black, 1958; De Witt et al., 1962), followed O by the serial estimation of plasma cortisol during the $N$ intravenous infusion of 30 units of A.C.T.H. over eight hours (Cameron and Kilborn, 1964).

T A B LE I

COMPARISON BETWEEN PREDNISONE AND A.C.T.H. GROUPS

\begin{tabular}{|c|c|c|c|c|c|c|c|}
\hline \multirow{2}{*}{ Group } & \multirow{2}{*}{$\begin{array}{l}\text { No. of } \\
\text { Patients }\end{array}$} & \multicolumn{2}{|c|}{ Sex } & \multirow{2}{*}{$\begin{array}{c}\text { Mean } \\
\text { Age } \\
\text { (years) }\end{array}$} & \multirow{2}{*}{$\underset{\substack{\text { Mean } \\
\text { (years) }}}{\stackrel{\text { yeation }}{ }}$} & \multicolumn{2}{|c|}{ A.C.T.H. Response Test } \\
\hline & & $\mathbf{M}$ & $\mathbf{F}$ & & & Normal & Subnormal \\
\hline $\begin{array}{l}\text { Prednisone } \\
\text { A.C.T.H. }\end{array}$ & $\begin{array}{l}14 \\
12\end{array}$ & $\begin{array}{l}7 \\
7\end{array}$ & $\begin{array}{l}7 \\
5\end{array}$ & $\begin{array}{l}33 \cdot 1 \\
36 \cdot 6\end{array}$ & $\begin{array}{l}14 \cdot 4 \\
17 \cdot 5\end{array}$ & $\begin{array}{l}4 \\
3\end{array}$ & $\begin{array}{r}10 \\
9\end{array}$ \\
\hline
\end{tabular}


Treatment was stopped abruptly at least 48 hours before the investigations were carried out; the longest interval after stopping treatment was 72 hours.

\section{RESULTS}

PREDNISONE GROUP The results are set out in Table II, and the individual changes in the eighthour plasma cortisol levels following A.C.T.H. stimulation are shown in Figure 1.

A.C.T.H. response test Before receiving prednisone 10 patients had a diminished response to

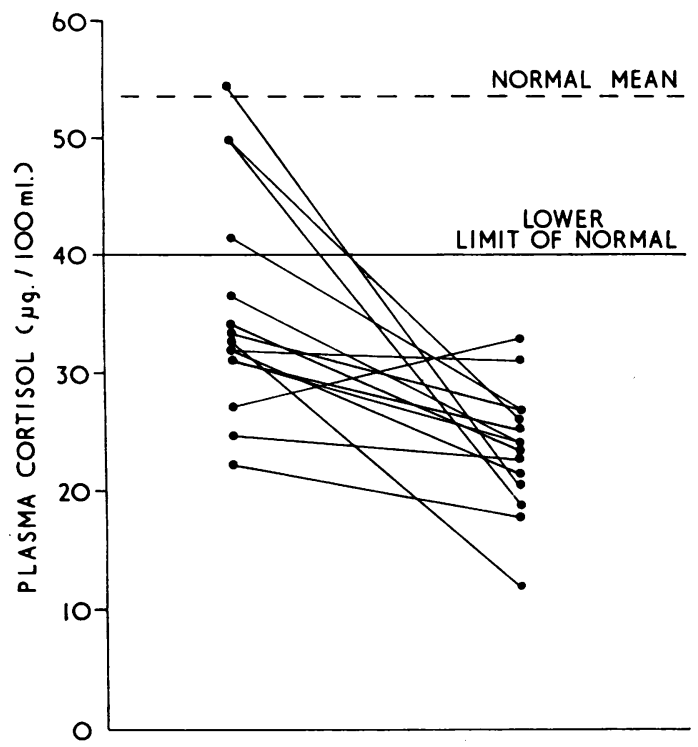

FIG. 1. A.C.T.H. response test. Eight-hour plasma cortisol before and after prednisone therapy.
A.C.T.H. ('subnormal') and four had a normal response ('normal'). After treatment the mean plasma cortisol levels rose by $11.3 \mu \mathrm{g} . / 100 \mathrm{ml}$., from $13 \cdot 1 \quad($ S.D. $\pm 7 \cdot 0) \mu \mathrm{g} . / 100 \mathrm{ml}$. to $24 \cdot 4$ (S.D. $\pm 6 \cdot 2) \mu \mathrm{g} . / 100 \mathrm{ml}$. after eight hours' stimulation with A.C.T.H., compared with a rise of $19 \cdot 8$ $\mu \mathrm{g} . / 100 \mathrm{ml}$. , from $16 \cdot 1$ (S.D. $\pm 7 \cdot 6) \mu \mathrm{g} . / 100 \mathrm{ml}$. to 35.9 (S.D. \pm 9.9$) \mu \mathrm{g} . / 100 \mathrm{ml}$. before treatment. The difference between the eight-hour levels $(11.5$ $\mu \mathrm{g} . / 100 \mathrm{ml}$.) is significant (S.E. $3.2 ; \mathbf{P}<0.005$ ), but the difference between the basal levels (3.0 $\mu \mathrm{g} . / 100 \mathrm{ml}$.) is not significant (S.E. 2-2; $\mathbf{P}=\mathbf{0} \cdot 2$ ). When the results of the 'subnormal' and 'normal' groups are considered separately, there is no significant change in the mean basal levels, the mean decrease in the 'subnormal' group being $3.3 \mu \mathrm{g} . / 100 \mathrm{ml}$. $(17 \cdot 1 \rightarrow 13.8 \mu \mathrm{g} . / 100 \mathrm{ml}$.) and in the 'normal' group $2.1 \mu \mathrm{g} . / 100 \mathrm{ml}$. (13.5 $\rightarrow 11.4$ $\mu \mathrm{g} . / 100 \mathrm{ml}$.). After eight hours' A.C.T.H. stimulation, the 'subnormal' group showed a fall of $6 \cdot 1$ $\mu \mathrm{g} . / 100 \mathrm{ml}$. after treatment $(30.6 \rightarrow 24.5 \mu \mathrm{g}$. $/ 100$ $\mathrm{ml}$.; P 0.01-0.02) and the 'normal' group a fall of $25 \cdot 2 \mu \mathrm{g}$. $/ 100 \mathrm{ml}$. $(49 \cdot 3 \rightarrow 24 \cdot 1 \mu \mathrm{g}$. $/ 100 \mathrm{ml}$.).

The 'normal' group is too small for a confident statistical comparison to be made, but it is clear that it accounts for most of the fall of the group as a whole.

Interestingly enough, one patient in the 'subnormal' group showed a small rise in response from $27.0 \mu \mathrm{g} . / 100 \mathrm{ml}$. to $33.0 \mu \mathrm{g} . / 100 \mathrm{ml}$. at eight hours.

Cortisol production rate The mean cortisol production rate before prednisone was $9.0 \mathrm{mg}$. $/ 24$ hours, and after treatment $6.5 \mathrm{mg}$. $/ 24$ hours, a decrease of $2.5 \mathrm{mg} . / 24$ hours. This difference is not significant (S.E. $1.25 ; \mathrm{P}>0.05$ ).

TABLE II

MEAN BASAL AND EIGHT-HOUR PLASMA CORTISOL LEVELS FOLLOWING A.C.T.H. STIMULATION, AND BASAL CORTISOL PRODUCTION RATES IN 14 PATIENTS BEFORE AND AFTER PREDNISONE THERAPY

\begin{tabular}{|c|c|c|c|c|c|c|c|c|c|c|c|}
\hline & \multicolumn{7}{|c|}{$\begin{array}{c}\text { Plasma Cortisol } \\
(\mu \mathrm{g} . ! 100 \mathrm{ml} .)\end{array}$} & \multirow{2}{*}{\multicolumn{4}{|c|}{$\begin{array}{l}\text { Cortisol Production Rate } \\
\text { (mg./24 hours) }\end{array}$}} \\
\hline & \multirow{3}{*}{$\begin{array}{c}\text { No. of } \\
\text { Patients }\end{array}$} & \multicolumn{3}{|c|}{ Basal } & \multicolumn{3}{|c|}{$\begin{array}{c}\text { After } 8 \text { Hours' } \\
\text { A.C.T.H. Stimulation }\end{array}$} & & & & \\
\hline & & \multicolumn{2}{|c|}{$\begin{array}{l}\text { Treatment with } \\
\text { Prednisone }\end{array}$} & \multirow{2}{*}{ Difference } & \multicolumn{2}{|c|}{$\begin{array}{l}\text { Treatment with } \\
\text { Prednisone }\end{array}$} & \multirow{2}{*}{ Difference } & \multirow{2}{*}{$\begin{array}{l}\text { No. of } \\
\text { Patients }\end{array}$} & \multicolumn{2}{|c|}{$\begin{array}{c}\text { Treatment with } \\
\text { Prednisone }\end{array}$} & \multirow{2}{*}{ Difference } \\
\hline & & Before & After & & Before & After & & & Before & After & \\
\hline Total & 14 & $16 \cdot 1$ & $13 \cdot 1$ & $\begin{array}{c}-3 \cdot 0 \\
(P=0 \cdot 2)\end{array}$ & 35.9 & $24 \cdot 4$ & $\begin{array}{c}-11.5 \\
(P<0.005)\end{array}$ & 14 & $9 \cdot 0$ & 6.5 & $\begin{array}{c}-2.5 \\
(P>0.05)\end{array}$ \\
\hline $\begin{array}{l}\text { Response initially } \\
\text { subnormal }\end{array}$ & 10 & $17 \cdot 1$ & 13.8 & $-3 \cdot 3$ & $30 \cdot 6$ & $24 \cdot 5$ & $-6 \cdot 1$ & & & & \\
\hline $\begin{array}{l}\text { Response initially } \\
\text { normal }\end{array}$ & 4 & $13 \cdot 5$ & $11 \cdot 4$ & $-2 \cdot 1$ & $49 \cdot 3$ & $24 \cdot 1$ & $-25 \cdot 2$ & & & & \\
\hline
\end{tabular}


TAB LE II I

MEAN BASAL AND EIGHT-HOUR PLASMA CORTISOL LEVELS AFTER A.C.T.H. STIMULATION, AND MEAN CORTISOL PRODUCTION RATES BEFORE AND AFTER A.C.T.H. THERAPY

\begin{tabular}{|c|c|c|c|c|c|c|c|c|c|c|}
\hline \multicolumn{7}{|c|}{ Plasma Cortisol ( $\mu$ g. $100 \mathrm{ml})}$. & \multirow{2}{*}{\multicolumn{4}{|c|}{ Cortisol Production Rate (mg. 24 hours) }} \\
\hline \multirow{3}{*}{$\begin{array}{l}\text { No. of } \\
\text { Patients }\end{array}$} & \multicolumn{3}{|c|}{ Basal } & \multicolumn{3}{|c|}{ After 8 Hours' A.C.T.H. Stimulation } & & & & \\
\hline & \multicolumn{2}{|c|}{$\begin{array}{c}\text { Treatment } \\
\text { with A.C.T.H. }\end{array}$} & \multirow{2}{*}{ Difference } & \multicolumn{2}{|c|}{$\begin{array}{c}\text { Treatment } \\
\text { with A.C.T.H. }\end{array}$} & \multirow{2}{*}{ Difference } & \multirow{2}{*}{ No. of } & \multicolumn{2}{|c|}{$\begin{array}{c}\text { Treatment } \\
\text { with A.C.T.H. }\end{array}$} & \multirow{2}{*}{ Difference } \\
\hline & Before & After & & Before & After & & & Before & After & \\
\hline 12 & $\begin{array}{r}15 \cdot 3 \\
(11)^{1}\end{array}$ & $\begin{array}{r}13 \cdot 7 \\
(11)^{1}\end{array}$ & $\begin{array}{c}-1.6 \\
(P>0.5)\end{array}$ & $34 \cdot 4$ & $54 \cdot 8$ & $\begin{array}{c}+20.4 \\
(P<0.005)\end{array}$ & 9 & $13 \cdot 4$ & $22 \cdot 7$ & $\begin{array}{c}+9.3 \\
(P<0.05)\end{array}$ \\
\hline
\end{tabular}

1 Number of observations

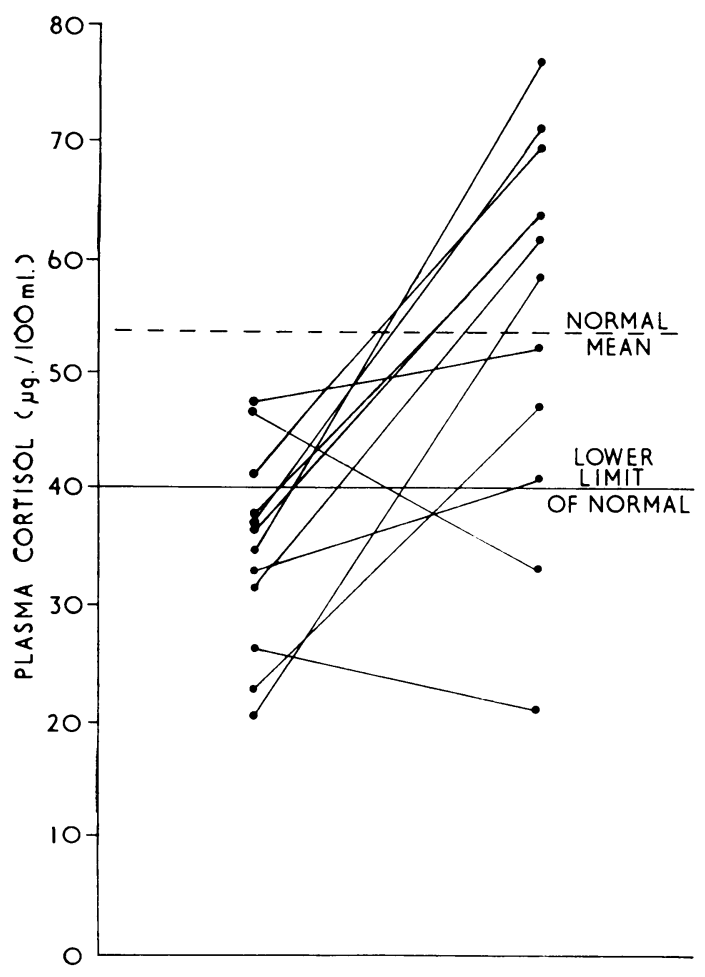

FIG. 2. A.C.T.H. response test. Eight-hour plasma cortisol before and after corticotrophin therapy.

A.C.T.H. GROUP The results from this group are summarized in Table III, and the individual changes in the eight-hour plasma cortisol after A.C.T.H. stimulation are shown in Figure 2.

A.C.T.H. response test After two months' treatment with corticotrophin, there was no significant change in the mean basal level, which fell by $1.6 \mu \mathrm{g} . / 100 \mathrm{ml}$. $(15.3 \rightarrow 13.7 \mu \mathrm{g} . / 100 \mathrm{ml}$.; $\mathbf{P}>0.5$ ). On the other hand, the mean eight-hour results showed an increase of $20.4 \mu \mathrm{g} . / 100 \mathrm{ml}$.
$(34.4 \rightarrow 54.8 \mu \mathrm{g} . / 100 \mathrm{ml} . ; \mathrm{P}<0.005)$. Before treatment nine patients had a diminished response and three were in the lower range of normal. After treatment 10 patients achieved a normal response. Of the two patients whose response did not increase after treatment, one, initially in the lownormal range at $46.5 \mu \mathrm{g} . / 100 \mathrm{ml}$, , fell to 33.0 $\mu \mathrm{g} . / 100 \mathrm{ml}$., and the other, initially very low at $25.7 \mu \mathrm{g} . / 100 \mathrm{ml}$., fell to $20.5 \mu \mathrm{g} . / 100 \mathrm{ml}$. There is no apparent reason why these two patients did not respond to A.C.T.H. therapy; there is no doubt that they received A.C.T.H. for at least two months, although in the second case it was stopped inadvertently for 10 days half-way through the course, after which the patient had a further six weeks' treatment.

Cortisol production rate This was estimated in nine of the 12 patients. The mean result before treatment was $13.4 \mathrm{mg}$. $/ 24$ hours, which rose to $22.7 \mathrm{mg}$. $/ 24$ hours after treatment, a rise of $9 \cdot 3$ mg. $/ 24$ hours. This rise is statistically significant (S.E. $3.5 ; \mathrm{P}<0.05$ ). In two patients the cortisol production rate fell after treatment by $3.3 \%$ and $3.1 \%$ respectively. Although there is a rise in both the mean cortisol production rate and the mean response to A.C.T.H. after treatment, there is no correlation between either the absolute or percentage change in the cortisol production rates and the change in response to A.C.T.H. in the individual case, nor is there significant correlation between the change in the cortisol production rates and the post-treatment basal plasma cortisol figures.

LONG-TERM STEROID TREATMENT For purposes of comparison, the results from nine patients who had received corticosteroid treatment for some time before investigation are included. The details are set out in Table IV. The mean basal plasma cortisol was 9.4 (S.D. \pm 5.9$) \mu \mathrm{g} . / 100 \mathrm{ml}$, and after stimulation for eight hours the mean level had risen to $24 \cdot 7$ (S.D. $\pm 11 \cdot 2) \mu \mathrm{g} . / 100 \mathrm{ml}$. 
TA B LE IV

AGES, DURATION OF ASTHMA, DURATION OF STEROID TREATMENT, AND BASAL AND EIGHT-HOUR PLASMA CORTISOL LEVELS WITH A.C.T.H. STIMULATION IN NINE PATIENTS TREATED WITH LONG-TERM STEROIDS BEFORE TESTING

\begin{tabular}{c|c|c|c|c|c|c}
\hline & $\begin{array}{c}\text { Age } \\
\text { (years) }\end{array}$ & $\begin{array}{c}\text { Duration } \\
\text { of Asthma } \\
\text { (years) }\end{array}$ & $\begin{array}{c}\text { Duration } \\
\text { of Steroids } \\
\text { (months) }\end{array}$ & \multicolumn{2}{|c|}{$\begin{array}{c}\text { A.C.T.H. Response Test } \\
\text { Plasma Cortisol ( } \mu \mathrm{g} .100 \mathrm{ml} \text {.) }\end{array}$} \\
\hline $\begin{array}{c}\text { Mean } \\
\text { Range }\end{array}$ & $15-56$ & $2-40$ & 6 Beeks-4 years & $\begin{array}{c}9.4 \\
\text { S.D. } \pm 5.9\end{array}$ & Eight-hour \\
\hline
\end{tabular}

TABLE V

DISTRIBUTION OF CLINICAL RESPONSE IN BOTH GROUPS OF PATIENTS AND RELATION OF CLINICAL RESPONSE TO THE CHANGE IN VENTILATORY TESTS

\begin{tabular}{|c|c|c|c|c|c|}
\hline & \multirow{2}{*}{$\begin{array}{c}\text { Clinical } \\
\text { Grade of } \\
\text { Improvement }\end{array}$} & \multirow{2}{*}{$\begin{array}{c}\text { No. } \\
\text { of } \\
\text { Cases }\end{array}$} & \multirow{2}{*}{$\begin{array}{l}\text { Mean Change } \\
\text { in } \frac{\text { F.E.V.1.0 }}{\text { V.C. }}(\%)\end{array}$} & \multicolumn{2}{|c|}{ Mean $\%$ Change in } \\
\hline & & & & F.E.V.1.0 & V.C. \\
\hline$\underset{\text { group }}{\text { A.C.T.H. }}$ & $\begin{array}{l}0 \\
1 \\
2 \\
3\end{array}$ & $\begin{array}{l}1 \\
6 \\
4 \\
1\end{array}$ & $\begin{array}{c}-3 \\
-5 \\
(-40 \text { to }+23) \\
+5 \\
(-5 \text { to }+23) \\
+4\end{array}$ & $\begin{array}{c}+20 \\
+9 \\
(-25 \text { to }+94) \\
+47 \\
(0 \text { to }+183) \\
+43\end{array}$ & $\begin{array}{c}+29 \\
0 \\
(-20 \text { to }+27) \\
+18 \\
(-4 \text { to }+50) \\
+31\end{array}$ \\
\hline $\begin{array}{l}\text { Prednisone } \\
\text { group }\end{array}$ & $\begin{array}{l}0 \\
1 \\
2 \\
3\end{array}$ & $\begin{array}{l}1 \\
3 \\
6 \\
4\end{array}$ & $\begin{array}{c}-33 \\
-16 \\
(-21 \text { to }+24) \\
-1(5 \text { cases }) \\
(-13 \text { to }+18) \\
+20(3 \text { cases }) \\
(+2 \text { to }+47)\end{array}$ & $\begin{array}{c}-45 \\
+\quad 2 \\
(-35 \text { to }+40) \\
+23 \\
(+2 \text { to }+70) \\
+239 \\
(+6 \text { to }+550)\end{array}$ & $\begin{array}{c}-16 \\
+31 \\
(+6 \text { to }+70) \\
+28 \\
(+4 \text { to }+92) \\
+109 \\
(+7 \text { to }+299)\end{array}$ \\
\hline
\end{tabular}

F.E.V.1.e, forced expiratory volume (one second); V.C., vital capacity

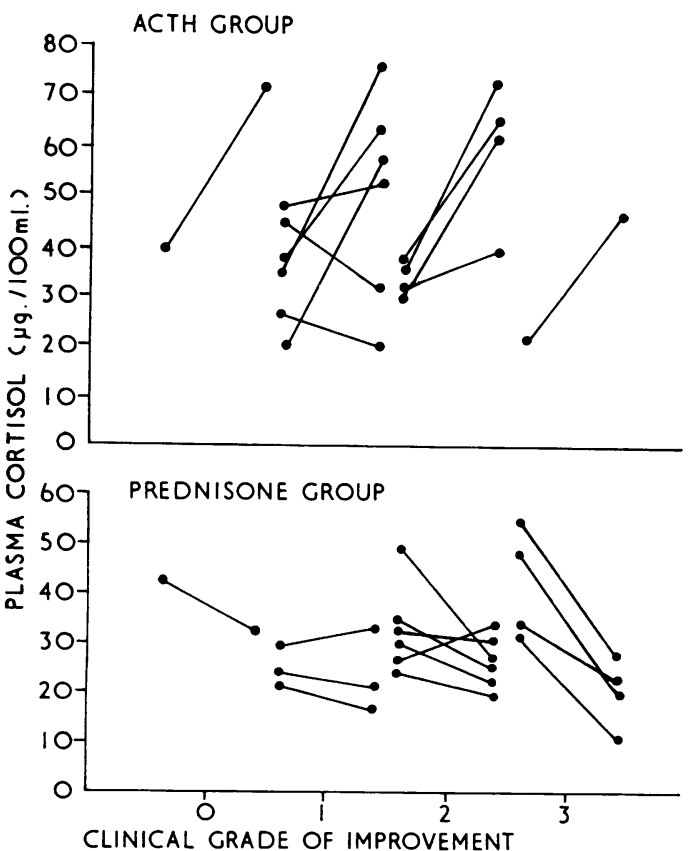

FIG. 3. Individual results of eight-hour plasma cortiso levels before and after treatment, grouped by clinical grade of imrrovement.
CLINICAL RESPONSE The clinical response to treatment was divided into four grades: 0 , no improvement ; 1 , decreased dyspnoea and a decrease in frequency and/or severity of acute attacks ; 2, marked decrease in dyspnoea and only occasional acute attacks of wheezing, of less severity and usually responding quickly to bronchodilator drugs ; 3 , complete relief of symptoms, no dyspnoea, and no wheezing.

All patients were seen at frequent intervals, and on completion of treatment they were assigned to the appropriate grade. After this grading the results of the ventilatory tests were analysed. Table $\mathrm{V}$ shows the number of patients in each clinical grade. The improvement in ventilatory capacity agrees broadly with the clinical assessment.

When the grade of clinical improvement is compared with the alteration in response to A.C.T.H. (as shown by the eight-hour level), no consistent pattern emerges (Fig. 3). It is not surprising that this is so in the prednisone group, since the response was depressed to similar levels in all cases; but in the A.C.T.H. group there was no relation between the magnitude of change in response and the degree of symptomatic relief. 


\section{DISCUSSION}

This study was not designed as a clinical trial of any particular treatment, and the improvement obtained in these patients was of the order expected from clinical experience in the use of prednisone and corticotrophin. There were more patients showing greater improvement in the prednisone group; it may be that this difference is due to the prednisone group receiving substitution therapy greater than is needed for physiological requirements, whereas the A.C.T.H. group was dependent on endogenous steroid production for a therapeutic effect.

Most patients in the A.C.T.H. group showed a considerable increase in adrenocortical activity after treatment; this was reflected in the cortisol production rate as well as by the A.C.T.H. response test, although it should be noted that there was no apparent correlation between the individual changes in the cortisol production rates and the A.C.T.H. response tests. The normal mean basal plasma cortisol after treatment may be explained by the fact that it only reflects the situation at an instant in time rather than over 24 hours, and by the wide individual variations in plasma cortisol due to many influences; indeed, although every care was always taken to minimize any anxiety, it is possible that the second response test caused less stress to the patient.

Nevertheless, after prolonged stimulation by A.C.T.H., the adrenal cortex was capable of achieving a normal response in most of these patients. This suggests that the reduction in reserve found in the majority of patients before treatment may be secondary to inadequate stimulation by the anterior pituitary rather than to a primary defect of the adrenal cortex. However, adrenocortical hypertrophy (induced by the treatment) probably plays some part in the increase in response.

In the prednisone group, with the dose of prednisone used $(15 \mathrm{mg}$./day), there was no evidence of adrenal suppression in the resting state, but the A.C.T.H. response test demonstrated a considerable reduction in adrenal reserve. However, there was little difference in the adrenal reserve after prednisone between those patients with 'normal' and 'subnormal' responses initially.

It is interesting how similar are the results of the A.C.T.H. response test in the patients who received three months' prednisone therapy to those of the patients who had received corticosteroids for a much longer time before investigation. What is not apparent from this study is the pattern of recovery of response in our patients after stop- ping treatment, and whether this pattern is different in those with a 'normal' response and in those with a 'subnormal' response originally. But two patients (one 'normal' and one 'subnormal') who received two months' A.C.T.H. therapy after prednisone showed no evidence of recovery of responsiveness. However, it is well recognized (Bayliss, 1961) that there is considerable variation in adrenal recovery after corticosteroid therapy, and Treadwell, Savage, Sever, and Copeman (1963) indicate that the likelihood of recovery is related to the duration of treatment and that the total dose of steroids plays some part.

Treatment with corticotrophin will produce an enhanced response to A.C.T.H. stimulation, and these present studies show that it is capable of restoring normal adrenal responsiveness in the majority of continuous asthmatics who had a diminished reserve before treatment; it is not yet known how long these patients will continue to show a normal or enhanced response.

Although it is said that the administration of A.C.T.H. will depress the release of endogenous corticotrophin, the position is not clear. For instance, Plager and Cushman (1962) demonstrated pituitary hyporesponsiveness to metyrapone (Metopirone) in six patients pre-treated with A.C.T.H., but Holub, Wallace, and Jailer (1960) found a normal response to metyrapone in six patients who had received A.C.T.H. therapy for a considerable time.

The functional significance of adrenal hyporesponsiveness is uncertain. It is considered that corticosteroid therapy inhibits endogenous corticotrophin and may depress adrenocortical activity directly (Danowski, Bonessi, Sabeh, Sutton, Webster, and Sarver, 1964). But Farmer, Hill, Pittman, and Herod (1961) presented evidence that there are two mechanisms concerned with corticotrophin release, one being mediated through the neurohypophysis in response to stress and the other through the pituitary-adrenal 'feed-back system'. Estep, Island, Ney, and Liddle (1963) have shown that response to stress is not affected by the acute administration of cortisol, and they suggest that a stressful situation may override the 'feed-back' mechanism as long as the adrenal cortex is capable of responding to corticotrophin.

It has been widely assumed that one of the major hazards of corticosteroid therapy is an inability to respond to acute stress, but biochemical confirmation of this is confined to a few cases. Indeed, Sampson, Winstone, and Brooke (1962) showed a normal plasma cortisol response to surgical stress in 15 of 18 patients with ulcerative colitis treated with steroids, and Amatruda, 
Hollingsworth, D'Esopo, Upton, and Bondy (1960) presented evidence for an intact pituitary-adrenal axis in response to hypoglycaemic stress in patients previously treated with steroids and A.C.T.H.

Obviously this is a complex problem, but our initial studies seem sufficient to indicate its importance. These studies suggest that in the continuous asthmatic the adrenocortical reserve is frequently reduced and that this reduction in reserve can be corrected by exogenous A.C.T.H. If, as some evidence suggests, the depression of endogenous corticotrophin by A.C.T.H. therapy can be 'over-ridden' by stressful stimuli, this would appear to be an indication that in certain cases A.C.T.H. therapy is preferable to oral therapy initially, particularly in the younger patients and in those for whom short-term therapy is envisaged.

In addition, it seems that prednisone may rapidly reduce adrenocortical reserve, but that the degree of reduction is not dependent on the original level of the reserve and that even prolonged treatment does not necessarily depress it further. Whether the administration of A.C.T.H. can restore the previous situation is uncertain. In this context, the clinical syndrome of acute adrenal failure in response to stress (in both treated and untreated cases) is seen with surprising rarity in asthma, although the necessity of increasing steroid dosage during an exacerbation of the disease is well recognized.

Further investigation on the effects of stress and of treatment is necessary, but the widespread (and sometimes reckless) use of steroid treatment in asthma is an indication of the need for a rational application of a treatment capable of relieving both physical and economic distress in many individuals who can be helped in no other way.

\section{SUMMARY}

The effect of prednisone and corticotrophin therapy on adrenocortical function has been studied in a group of patients with continuous asthma by means of basal cortisol production rates and the plasma cortisol response to A.C.T.H. stimulation.

Previous work had shown that 19 of 26 patients investigated had an abnormally low response to A.C.T.H. stimulation.
Patients treated with prednisone showed a depression of response to stimulation, and the results are similar to those obtained from nine patients who had received long-term steroid therapy. The cortisol production rate was unchanged.

Most patients treated with A.C.T.H. showed an increase in the A.C.T.H. response test, showing that the reduced reserve demonstrated initially was reversible.

The significance and practical application of these findings are discussed.

We are grateful to Professor A. L. Latner and Dr. A. G. Ogilvie for their advice and encouragement, and to Dr. Ogilvie for allowing us to study patients under his care. One of us (J. R. K.) was in receipt of a grant from the Board of Governors, United Newcastle upon Tyne Hospitals.

We are indebted to Organon Laboratories for a supply of Cortrophin and to the United States National Institutes of Health, Bethesda, for a supply of Cortisol-4- ${ }^{14} \mathrm{C}$ to Professor Latner.

\section{REFERENCES}

Amatruda, T. T., Hollingsworth, D. R., D'Esopo, N. D., Upton, G. V., and Bondy, P. K. (1960). A study of the mechanism of the steroid withdrawal syndrome. Evidence for the integrity of the hypothalamic-pituitary-adrenal system. J. clin. Endocr., 20, 339.

Bayliss, R. I. S. (1961). In Adrenal Cortex, ed. G. K. McGowan and M. Sandler, p. 200. Pitman Medical Publishing Co., London.

Cameron, E. A., and Kilborn, J. R. (1964). Plasma cortisol and corticosterone response to infused corticotrophin in normal subjects. Clin. chim. Acta, 10, 308.

Cope, C. L., and Black, E. G. (1958). The behaviour of ${ }^{14} \mathrm{C}$-cortisol and estimation of cortisol production rate in man. Clin. Sci., $17,147$.

Danowski, T. S., Bonessi, J. V., Sabeh, G., Sutton, R. D., Webster, M. W., and Sarver, M. E. (1964). Probabilities of pituitaryadrenal responsiveness after steroid therapy. Ann. intern. Med., 61, 11 .

Estep, H. L., Island, D. P., Ney, R. L., and Liddle, G. W. (1963). Pituitary-adrenal dynamics during surgical stress. J. clin. Endocr., 23, 419.

Farmer, T. A., Hill, S. R., Pittman, J. A., and Herod, J. W. (1961). The plasma 17-hydroxycorticosteroid response to corticotrophin, SU-4885 and lipopolysaccharide pyrogen. Ibid., $21,433$.

Holub, D. A., Wallace, E. Z., and Jailer, J. W. (1960). Pituitary adrenocorticotrophin (ACTH) reserve in man following prolonged ACTH therapy. Ibid., 20, 1294.

Plager, J. E., and Cushman, P. (1962). Suppression of the pituitaryACTH response in man by administration of ACTH or cortisol. Ibid., 22, 147.

Robson, A. O., and Kilborn, J. R. (1965). Studies of adrenocortical function in continuous asthma. Thorax, 20, 93 .

Sampson, P. A., Winstone, N. E., and Brooke, B. N. (1962). Adrenal function in surgical patients after steroid therapy. Lancet, 2, 322 .

Treadwell, B. L. J., Savage, O., Sever, E. D., and Copeman, W. S. C. (1963). Pituitary-adrenal function during corticosteroid therapy. Ibid., $1,355$.

De Witt, G. F., Robson, J. S., and Stewart, C. P. (1962). Studies of hydrocortisone production as measured by isotope dilution techniques in adrenocortical diseases and in idiopathic hirsutism. Clin. chim. Acta, 7, 664 . 